\title{
THE DIACHRONIC EXPANSION OF PT. VOSSA MERCÊ $>$ VOCÊ AND SP. VUESTRA MERCED > USTED
}

\author{
A EXPANSÃO DIACRÔNICA DE PT. VOSSA MERCÊ > VOCÊ \\ E ESP. VUESTRA MERCED > USTED
}

Martin Hummel | CV | martin.hummel@uni-graz.at University of Graz

\begin{abstract}
The widespread use of Pt. você and Sp. usted in America is a well-known fact. However, the explanation for their diachronic expansion is still a puzzling question. Given the fact that Pt. voce and Sp. usted surfaced in Europe as late as the end of the $16^{\text {th }}$ century, many authors wonder how these address pronouns could have spread over the whole colonial territories of Portugal and Spain, at a time when the colonization process was largely accomplished. The paper shows that this puzzling question is ill put. Pt. você and Sp. usted are reduced grammaticalized results of Late Medieval Pt. vossa mercê and Sp. vuestra merced. Both diachronic data and $20^{\text {th }}$ century dialect data used for diachronic reconstruction show that an impressive bulk of reduced variants was in use already in the $16^{\text {th }}$ century. The late fixing of one of these reduced forms, Pt. você / Sp. usted, is a simple matter of standardization. In this process, the colonial civil and military administration played an important role. In Portugal, the variants associated with the path vossa mercê > você were largely used in dialects, but ruled out by Lisbon's elite. This is the reason why você is marginal in European Portuguese.
\end{abstract}

Keywords: Portuguese; Spanish; Address pronouns; Diachrony; Diachronic reconstruction.

Resumo: O extenso uso de pt. você e de esp. usted na América é um fato incontestável. No entanto, a explicação para a sua expansão diacrônica continua a ser uma questão aberta. Levando em conta que pt. você e esp. usted apareceram na Europa somente no final do século XVI, muitos autores se perguntam como tal expansão foi possível, num momento em que a colonização estava praticamente terminada. $\mathrm{O}$ artigo mostra que a questão é mal posta. Pt. você e esp. usted são resultados reduzidos da gramaticalização dos tratamentos medievais pt. vossa mercê e sp. vuestra merced. Tanto os dados diacrônicos como os dados dialetais do século XX, usados pela reconstrução diacrônica, mostram que houve um sem-fim de variantes reduzidas dessas formas nominais já no século XVI. A fixação tardia de uma só destas variantes, pt. você / sp. usted, foi uma simples questão de padronização. Neste processo, a administração colonial civil e militar teve um papel importante. Em Portugal, as variantes relacionadas ao processo diacrônico vossa mercê > você eram muito usadas nos dialetos, mas a elite lisboeta recusou este uso. Por este motivo, o pronome você tem um uso bastante marginal no português europeu.

Palavras-chave: Português; Espanhol; Formas de tratamento; Pronomes; Diacronia; Reconstrucção diacrônica. 


\section{Introduction}

The use of Pt. você 'you' and Sp. usted 'you' for addressing a single person is widespread in present-day Portuguese and Spanish. Given the geographic extension of their use, especially in Europe and America, it comes as no surprise that their functions vary considerably. Their functions range from respectful address (formality), to almost generalized usage (default), through to the expression of high intimacy or collective identity (see Section 2). This is the reason why the English glossing with 'you' needs specification, which, however, can only be added for given areas, e.g., você 'you (default, Brazil)', usted 'you (very formal, respectful or distant, Spain)'. The fact that they convey apparently contradictory functions, ranging from high formality to intimacy, is a challenge for linguistic explanation. Interestingly, Pt. você and Sp. usted show similar tendencies of variation. Hence, it is unlikely that variation operates at random. This underlines the methodological interest of a comparative approach.

The fact that the use of Pt. você and Sp. usted displays crucial similarities derives from their common origin: the use of the nominal forms of address Pt. vossa mercê and Sp. vuestra merced 'Your Grace' at court in the14th century (HAMMERMÜLLER, 2010, p. 514). Many European courts used analogous address formulae, e.g., Engl. Your Grace, thus following the Habsburg tradition (the uso de Borgoña 'etiquette of Burgundy' introduced by Charles V, and the so-called Leyes de cortesía by Charles' son Philip II). In other words, these forms of address came into use in a shared cultural context and in closely related Romance languages. Present-day Pt. você and Sp. usted are thus highly grammaticalized diachronic results of the same nominal model. Their diachronic grammaticalization as pronouns of address is, again, a shared feature of Portuguese and Spanish. By contrast, pronominalization did not occur, e.g., with Engl. Your Grace and It. Vostra Signoria, albeit for the latter, short forms were temporarily in use.

The common origin of Pt. você and Sp. usted suggests the idea of a comparative diachronic study aiming to explain the present-day variety of forms and functions, as well as the varying frequency of use, from marginal (Portugal, Spain) to almost generalized (Brazil, some varieties of Spanish).

Another puzzling question is the late spread of these pronouns in America. They are first attested by the end of the 16th century, at a time when the colonization process had basically been completed, as far as the establishment of American Spanish and Portuguese linguistic varieties is concerned. At that time, você and usted were each only one variant amongst a bulk of variants. Their standardization starts by the end of the 17 th 
century. So why do we find these pronouns everywhere? How could the most hidden American village introduce these pronouns? And, even more so, if we assume a European origin: why are they more generalized in the Americas as compared to Portugal and Spain?

This paper claims that the whole diachrony of address in Portuguese and Spanish is fundamentally a consequence of a process that replaces the Old Portuguese and Old Spanish pronouns vós/vos with the nominals vossa mercê / vuestra merced. The degree of substitution and the final configuration of their usage provide the cues for answering the above questions in terms of layering, conflation, or differentiation, that is, variation. The informal pronouns $t u / t u$ are marginal elements in this process. They are not in focus here. They basically intervene in America via late colonial influence, migration from Europe, schooling, and the extension of address practices that were originally inside families (taken in the broader sense of what is considered a family in a traditional Portuguese or Spanish village).

The distinction between public communication vs. family/familiar communication seems to be crucial. According to Luz (1958-1959, p. 221), in Old Portuguese texts $t u$ is almost always used in intimate relations. In addition, even at present, families practice considerably different patterns of address (e.g., OLIVEIRA, 2009, for Portugal). In this context, we have to bear in mind that during the first decades of colonization, the men who came to America had to leave both their family and their local community. This should have favored the use of the forms of address that were most likely to be used in public. For the sake of illustration, we may think of the striking contrast in present-day American Spanish between the widely documented manifold variation in address practices, and the fact that a person who is not a member of a given community will normally only be addressed with Sp. usted and/or the corresponding verb forms.

This paper is based on an analysis of the available bibliography on address. The layering processes will be systematically described in terms of phonetic, morphological, syntactic, and pragmatic inheritance. Inheritance is seen as a strong type of layering whereby the new form accepts some features from the former one.

Before proceeding to answer the questions outlined above (Sections 4 to 7 ), I provide some basic information concerning the use of você/usted (Section 2) and a feature-based approach that allows a description of contextual effects in terms of interaction between meanings of forms of address with given contexts (Section 3 ). 


\section{Some patterns in present-day variation}

This section provides a rough synthesis of address patterns in present-day usage.

\subsection{Formality (usted)}

The use of Sp. usted as a formal, respectful term of address is by far its most important and widespread function. However, the extension (frequency) of this function varies. In Spain, usted has become rather marginal, as a consequence of the general "informalization of communication" during the 20th century, reflected in the expansion of tú. In America, usted and/or the corresponding verb forms are more commonly used (and especially the plural ustedes), but there is considerable geolinguistic variation. To give an example, in Argentina usted was still widely used at the beginning of the 20th century (BERTOLOTTI, 2015, p. 50), but then informal vos expanded, as with tú in Spain, and consequently usted has now become marginal. Argentina is an exception in this way. The following citation shows the formal use of singular and plural in Ecuador (LAVENDER, 2017, my italics), which may exemplify a typical use in most American Spanish varieties:

(1) A: Hola mi nombre es $\mathrm{N}$ su nombre me suena conocido y su esposo también B: Creo que compartimos a lo mejor del mismo Pueblo q nos vio crecer [...]

A: Muchas gracias saludos también a ustedes gusto saber que nuestra gente del pueblo está bien $[\ldots]$

A: Hello, my name is $\mathrm{N}$; your name sounds familiar to me and so does your husband's ${ }^{1}$

B: I think we possibly stem from the same town that 'saw us growing up'

A: Thanks a lot, greetings also to you [plural], a pleasure to know that the people from our town are fine $[\ldots]$

In America, the plural ustedes is not marked for formality. In the citation, formality is only marked with the possessive $s u$ and lexical items, e.g., esposo.

\subsection{Default in public communication (usted)}

In Costa Rica and in the Venezuelan Spanish variety of Mérida, usted is the most generally used address pronoun. In Costa Rica, the general tendency is to use usted as the default form of address in public communication (MICHNOWICZ et al., 2016). Usted

\footnotetext{
${ }^{1}$ The English translation reproduces the highly inferential original text (all translations are my own).
} 
conveys respect, but not to the same degree as in Spain. It thus comes close to a default function. It is noteworthy that this general tendency goes hand in hand with different regional patterns, e.g., the generalized use of vos in Cartago as a symbol of regional identity (SCHMÖLZER, 2018). It may be added that there is a recent tendency to extend the use of vos in Costa Rica to the detriment of usted. As with vos in Cartago, usted plays a role as a marker of regional identity in Mérida (SOSA, 2009); it is the form of address preferred by this community.

\subsection{Usted of tenderness and respect}

Many American Spanish varieties have developed the pragmatic patterns of usted de cariño 'usted of tenderness and respect' and usted de enojo 'usted of annoyance', especially with children (2), but also in a couple (3):

(2) A: !Buenos días mi amor! Espero que esté mejor.

B: Gracias guapa mi muñeca preciosa. Sin usted q sería mi vida

(Ecuador, Facebook manager) (LAVENDER, 2017, my italics)

A: Good morning/afternoon my love! I hope you feel better.

B: Thanks my beautiful, precious doll. What would be of my life without you.

(3) —Listo, mi amor — exclamó de pronto a sus espaldas Margarita y lo condujo de vuelta a su pieza, donde cerró la puerta-. Pero, ¡cómo se le ocurre irse al lado, mi amor! Usted debe guardar las distancias, al fin y al cabo es el marindango mío. ¿O no? ¡Siéntese! ¿Un cafecito o una cervecita? (AMPUERO, 1998, p. 86, my italics)

"Ready, my love", shouted Margarita abruptly behind him, taking him back to his room, where she shut the door. "But how you could you do this, my love! You must keep your distance. After all, you are my man, aren't you? Please have a seat! A coffee or a beer?”

People may take tú as the usual form of address for their children or partners but switch to usted in situations of particular intimacy, tenderness, and care (see, e.g., HELINCKS, 2016, p. 293-302). 


\subsection{Usted of annoyance}

In the following Chilean Spanish example, a mother, who normally uses tú to address her daughter, switches to usted when she feels the necessity to utter an order:

(4) [Mother]: _ _Vaya haciendo su maleta!

[Daughter]: — —No pienso! ¡Me quedo!

[Mother]: -Mijita, los ríos arrastran piedras y las palabras embarazos. ¡La maletita!

[Daughter]: 一Yo sé cuidarme.

[Mother]: —Qué va a saber cuidarse usted! Así como la estoy viendo acabaría con el roce de una uña. Y acuérdese que yo leía a Neruda mucho antes que usted.

(SKÁRMETA, 1999, p. 54-6, my italics)

M: Go and pack your bags!

D: No way! I stay!

M:My daughter, rivers drag stones and words pregnancy. Your bags!

D: I know how to take care of myself.

M:What do you mean you know! As I see you, the first touch of a finger will make you render. Remember, I read Neruda long before you.

\subsection{Default (você), Brazil}

In Brazilian standard and in many Brazilian regions, você is the most common form of address. It often competes with $t u$, up to the point that both may be interchangeable, and some regions prefer tu over você. However, both pronouns usually combine with third person verb forms (vocêfaz, tu faz). Hence, unlike in Spanish, where usted may be opposed to informal tú or vos, Brazilian Portuguese você has almost lost this contrast. On the other hand, it is opposed to formal o Senhor, a Senhora, while Sp. usted fills the whole upper scale of formality. Hence, você only receives a slight pressure 'from above' (respectful o Senhor, a Senhora), but not 'from below' ( $t u$ ) (cf. RUMEU, 2013, on the use of você in Brazil since the 19th century; for general aspects see História dos pronomes de tratamento, 2015, and LOPES et al., 2018a,b). 


\subsection{Marginal você, Portugal}

In Portugal, você not only contrasts with informal tu and formal o Senhor / a Senhora, but its role overall is rather marginal. It may convey anger and annoyance in asymmetric relations, as well as a slightly higher degree of respect in symmetric relations such as friendship, especially as a situational switch in a conversation between people who generally use mutual $t u$. The expression of anger, but also of informal respect, calls to mind the - certainly stronger - contrast of Sp. usted de cariño/enojo. As pointed out by Bermejo and Guilherme (2018, p. 361), "not even the Portuguese speakers agree in determining the contexts where it [você $]$ can be employed". In other words, in many situations they would feel unease employing it.

\section{Functional principles underlying diachronic change}

The functions of forms of address are often described with concepts such as politeness, courtesy, intimacy, formality, informality, power, solidarity, etc. While these concepts may adequately characterize given situations or established scenarios of address, they cannot be used for a baseline functional description. Such a functional description requires clear complementary features that gain full pragmatic meaning by interacting with contextual features.

In the following example, Sp. tú is used to aggressively address an old man:

(5) - ¿Paco? - preguntó el Suizo desde el umbral. Su voz resonó clara- ¿ ¿Paco, eres tú? [...]

-Busco a Plácido del Rosal -masculló mientras se acercaba.

-No lo conozco- repuso el librero titubeando.

-Lo conociste hace más de treinta años y la memoria no te puede fallar tanto reclamó con un hilo de voz el Suizo [...].

-De veras, no sé de quién me habla.

-Sé a qué vino y lo que le diste.

(AMPUERO, 1998, p. 105, my italics)

“Paco?”, asked The Swiss from the threshold. His voice was clear. "Are you Paco?” "I am searching for Plácido del Rosal", he mumbled as he approached.

"I don't know him", replied the bookseller, staggering.

"You knew him over thirty years ago, and your memory can't fail so much", 
objected The Swiss in a thin voice.

"Sincerely, I don't know whom you are talking about".

"I know what he came for and what you gave him".

In this case, tú does not convey intimacy, informality, or solidarity. The situation itself may be described in terms of (physical) power, but the pronoun tú does not convey this information since it is mostly used in contexts of solidarity, intimacy, informality (see BROWN; GILMAN, 1960, for these terms). The citation refers to a context where social conventions of respect are violated, in this case, using tú to address an old man in his house without knowing him. Interestingly, the fact that tú conveys neither solidarity nor intimacy does not mean that the pronoun does not convey its meaning. Indeed, the violation of social norms is conveyed with basic features of tú: [- respect], [- distance]. Social conventions are violated exactly because the aggressor uses tú to convey a lack of respect and distance. Consequently, meaning and pragmatic effects have to be differentiated in linguistic analysis.

Similar problems of analysis with some of the most usual terms arise when we try to explain the American Spanish practices of frequently switching the forms of address during the same conversation with the same person(s). Helincks (2016, p. 40; on general aspects see HUMMEL, in print) cites a letter from 19th century Argentina where the same person is addressed with three forms of address: tuteo, voseo, usted. She further provides abundant evidence for address switching in present-day spoken Chilean Spanish. Terms such as intimacy, informality, politeness, solidarity, power are too strong since they aim to characterize a whole situation or even an assumedly stable social relation. In reality, the speakers rely on more basic features expressed by the forms of address to modulate their interaction with another person. In familiar or intimate situations, switching address comes close to linguistically caressing the interlocutor, playfully increasing or decreasing the degree of respect.

In all these contexts, I claim, $t u / t u ́$ convey the same function insofar as they signal "directness", that is, a type of communication which is not mitigated by considerations of politeness, respect, social distance, etc. In Spanish varieties where tú competes with vos, as in Chilean Spanish, the latter may mark a still closer, more direct relationship. By contrast, usted conveys "respect" in all situations, including in intimate communication, e.g., the usted de cariño. Interestingly, all pronouns expressing respect rely on indirect patterns 
of address: 3rd person singular (usted / você), second person plural (vós / vos) ${ }^{2}$ or 3rd person plural (ustedes / vocês), also in other languages. Table 1 suggests analyzing these pronouns of address with some basic features:

Table 1. Basic semantic-pragmatic features of tu/tú and você/usted.

$\begin{array}{lllll}\text { Function } & \begin{array}{l}\text { Linguistic } \\ \text { Relation }\end{array} & \begin{array}{l}\text { Interpersonal } \\ \text { Implicature I }\end{array} & \text { Implicature II } & \\ \text { Tu/tú: } & \text { 2nd person } & + \text { direct } & \text { - distance } & \text { - respect } \\ \text { Você/Usted: } & \text { 3rd person } & \text { - direct } & \text { + distance } & \text { + respect }\end{array}$

Table 1 reads as follows: Grammatically, the 1st and the 2 nd persons are those which are directly involved in a communication act. Hence, their relation is direct and not distant in terms of spatial deixis. As a first semantic-pragmatic development, this baseline feature may be read in terms of personal "closeness" (- distance). Directness may further be interpreted in terms of not overtly marked respect. In situations such as that quoted in (5), where social norms require respect, the use of $t u / t u$ is disrespectful. By contrast, the 3rd person grammatically refers to a "distant" person not directly involved in communication. Hence, its inferential metaphorical development starts from baseline "indirectness". Now, indirect communicative strategies are often used to convey politeness (BROWN; LEVINSON, 1987), which means, in this case: respect. Interestingly, Sp. usted may separately convey the features "+respect" or "+distance", according to the context. This is certainly relevant from a cognitive linguistic point of view insofar as spatial distance in the pronominal pronoun system metaphorically underlies respect and distance in address. Pragmatically speaking, usted is used for individual distancing, as well as for expressing respect. The scenario of usted de cariño happens when the intimate situation neutralizes the feature $[+$ distance], thereby foregrounding the feature $[+$ respect $]$. By contrast, the usted de enojo foregrounds the feature [+distance].

These features may weaken in varieties where the paradigm of address is simpler or more complex. The effect of simplification occurs in the case of the largely prevailing modern use of vos in Argentina, of tú in Spain, usted in Mérida (Venezuela), você in Brazil, or $t u$ in Latin. The effect of complexity happens in the complex address system of European Portuguese. Since we are dealing with pro-drop languages, the overt or covert use of the subject pronouns may also be used to mitigate the binary opposition in Table 1 (see HUMMEL, in print).

\footnotetext{
${ }^{2}$ In present-day American Spanish, vos competes with tú, but, diachronically, it began as a respectful form of address.
} 
In sum, it seems to be possible to provide a baseline explanation for using forms of address in terms of fundamental grammatical features and their pragmatic inferential metaphorical development(s). It is obvious, however, that this approach cannot explain any specific historical development. Thus, this section has only defined the features that I assume to be interacting within a given context (situation, personal relation, social relation, in-group/out-group relation, public/private, etc.).

\section{The default use of Pt. vós and Sp. vos in the old language (public domain)}

Until the early 15th century, Pt. vós could be used in all situations, from addressing common people to addressing the king, if the intention was to convey respect:

\footnotetext{
O vós como tratamento cortês universal e único, apto para ser utilizado em qualquer circunstância, mesmo em alocuções dirigidas ao rei, só esteve em Portugal em vigor até aos princípios do século XV (CINTRA, 1972, p. 46)
}

Used as the general and sole polite form of address, which could be used in all situations, even addressing the king, vós was used in Portugal only until the beginning of the 15 th century

The use of vós as default variant in all types of polite/respectful address apparently declined as early as the beginning of the 15th century. The fact that the default role of Pt. vós in the pragmatic domain of respect declined does not mean that this function was abruptly lost. According to the same author, vós conserved its default potential until the first half of the 16th century:

\footnotetext{
No teatro de Gil Vicente vós nunca deixou de ser possível como tratamento respeitoso, em nenhuma circunstância.

In Gil Vicente's theatre, it was still possible, in all circumstances, to use vós for respectful address.
}

The weakening of vós in the early 15th century claimed by Cintra would explain why it plays no significant role in the diachrony of American Portuguese, unlike what happens with its Spanish equivalent vos.

As for Spanish, King (2010, p. 535) and Moreno (2002, p. 44) observe that Sp. vos and the corresponding verb forms were still used as the unmarked form of address in the Spanish Golden Age, that is, until the beginnings of the 17th century. It should be added 
that this only holds for the public domain, because tú was frequently used in private contexts. Theatre plays - which have been primarily used for diachronic research on address - use forms of address in order to increase fun and suspense. This fact somehow hides the real importance of simply using vos for everyday public life in the available linguistic studies (HUMMEL, in print). In addition, the fact that the first phase of colonization was undertaken by men suggests the relevance of the following observation in King (2010, p. 546) on the use of vos in the Golden Age:

la forma vos era el tratamiento que se usaba par excellence entre los hombres de esta época, mientras que en las conversaciones entre mujeres se encontraba con mucha más frecuencia el tú.

vos was the form of address used par excellence between the men of that epoch, whereas tú was much more frequent in conversations between women.

The default status of Sp. vos on the eve of America's colonization can also be corroborated via diachronic reconstruction. In Hispanic America, the use of vos was and still is widespread, especially in the colonial periphery, that is, outside the vice-royalities (today Mexico and Peru) and the Antillean bridging area, where the colonial influence caused a secondary layering of tú replacing vos (see overview in CARRICABURO, 1997). In other words, vos was commonly used before the later layering of $t u$ changed the linguistic panorama according to the areas. If we bear in mind that the American Spanish varieties, especially those situated at the colonial periphery, were closely related to the traditions of Spanish as it was spoken (not written) in the Iberian peninsula, it is legitimate to argue that the American Spanish geolinguistic distribution of address corroborates the hypothesis of a widespread or generalized use of vos in Spain, at least in spoken public communication, during the first decades if not the first century of colonization.

One might object that it is circular to explain American Spanish voseo with the use in Spain and the use of vos in Spain with American Spanish, but if independent empirical data corroborate either situation, the data indeed confirm the hypothesis. The downgrading of vos from respectful addressing to a familiar form competing with tú was mainly due to the additional layering of respectful vuestra merced / usted, which is the process we will discuss in greater detail in the following section.

By analogy, the fact that Pt. vós has left no traces in America also supports Cintra's argument of early declining vós in Portugal. It had apparently already been replaced by vossa mercê and other nominals of this type. The fact that the most generalized usage of 
você in present-day Brazilian Portuguese is still a property of the areas that were first colonized, the North-East around Salvador de Bahia, the former capital, supports the idea of an early replacement of vós by nominal in Portugal. As in colonial Spanish America, later migration favored the implementation of $t u$, e.g., in the State of Maranhão and the Azorian immigration in the Island of Florianópolis. Unlike in American Spanish, the use of Pt. $t u$ in Brazil is not a sign of education. Tu is a simple alternative to você. Significantly, tu generally combines with the same third person verb forms as você. Consequently, in Maranhão the use of $t u$ itself is not a sign of education, but second person agreement is such a sign. In some varieties, e.g., in the lower-class areas of Rio de Janeiro, its use may even be associated with this social stratum, even if the present-day tendency in Rio de Janeiro links the alternation você/tu more with informality than with sociolinguistic features (LOPES et al., 2009; SILVA, 2011).

\section{The pronominalization of vossa mercê/vuestra merced}

The pronominalization from vossa mercê to você and from vuestra merced to usted happened in a time span beginning with the 14th century and ending in the 17 th century, as far as the standard variants are concerned. The process has been thoroughly discussed, especially for Spanish, because of its interest for grammaticalization theory (noun phrase > pronoun). In fact, the standardized forms você/usted emerged from countless phonetic variants that reflect different stages or different paths of development, as tentatively and selectively reflected for Spanish in Table 2 (cf. CÁRCELES, 1923; DE JONGE; NIEUWENHUIJSEN, 2009, p. 1605; RIVERA, 2006; BERTOLOTTI, 2010; HAMMERMÜLLER, 2010, p. 523):

Table 2. Diachronic overview of the development of Sp. vuestra merced > usted. vuestra merçed (14th century) vuesa merçed vuesanced vuesarçed usancé(d) voarçed, vuarçed, vuerçed $\operatorname{voaçe}(d), \operatorname{vuaçe}(d), \operatorname{vueçe}(d)$ uce (d)

vuested vusted usted (after 1550)

The increasing number of studies on the diachrony of usted permanently provides new and older attestations, as well as other variants. The linguists' enthusiasm for providing a first attestation is, however, somehow misleading. Many, if not most, variants coexisted, albeit not necessarily with the same geolinguistic, sociolinguistic, or textlin- 
guistic distribution. For the sake of illustration, it may suffice to look at the geolinguistic distribution of Pt. você and its variants in the 20th century (see 7.2). In line with this, Díaz Collazos (2015, passim) shows that the variant Sp. vusté is still used in the 20th century in rural areas of Colombia. This is the reason why Table 2 does not include the years of first attestation. It reflects three phonetically plausible clines. In this context, phonetics may be a better hint for diachrony than attestation. According to the above-mentioned authors, these clines are compatible with the available attestations.

For the purpose of this paper, the relevant fact is that the phonetically altered followers of vuestra merced provide clear evidence for their widespread use in spoken language. Both the phonetic "erosion" as such and the multitude of variants underline this fact. De Jonge and Nieuwenhuijsen (2009, p. 1646-1649) mention 34 different variants of vuestra merced. Hence, it is clear that original vuestra merced was firmly established in the commonly used spoken language when colonization started, or that the process of diffusion from formal to informal communication was already significantly engaged. Consequently, this supports the assumption of vuestra merced having paralleled vos in the oral tradition. Both reached America where they deeply rooted.

In an interesting paper on private letters sent from America to Andalusia in the second half of the 16th century, Bentivoglio (2003) observes that vos is still preferred over vuestra merced: 23 letters consistently use vos, 13 vuestra merced, and 16 present alternation. Twelve of the letters that systematically use vuestra merced stem from the last decades ( 1572 to 1591 ). She also quotes a metalinguistic comment from 1533 where the use of vos was criticized. This means that top-down social and colonial pressure favored the use of vuestra merced. Bentivoglio also confirms its belonging to formal communication, e.g., letters directed to the colonial administration, while vos was already informal. Regarding the previous paragraph, this means that if the diffusion of vuestra merced had started in the early 16th century, it started from above in domains of formal communication. In this sense, the spread of vuestra merced may be explained via top down colonial pressure on America (HUMMEL, in print). The plural vuestras mercedes followed the same path in this period (CAMPOS, 2019, p. 130).

It is noteworthy that the spellings você/usted are not crucial for the grammaticalization process insofar as, e.g., vusted is no less grammaticalized. Hence, we have to distinguish the grammaticalization process as such from the establishment of a standardized spelling for the reduced pronominal form, that is, usted, in the case of Spanish, and você, in Portuguese. It is thus highly improbable that the generalization of você/usted is a sponta- 
neous outcome of grammaticalization. Generalization and standardization presuppose a normative ${ }^{3}$ process of selection from a wide array of alternatives. In addition, the reduced forms competed with the long forms during the 17th and 18th centuries, conveying different degrees of respect (see GARCÍA-GODOY, 2015 on Spain and GUTIÉRREZ MATÉ, 2012 on Caribbean American Spanish).

In a recent study, García-Godoy (2016) calls into question the traditional diachrony of usted (see Table 2), arguing that the profusion of variants is methodologically biased by the exploration of literary sources, especially theatre, which favor the use of playful variation. In fact, in her corpus of Andalusian texts (Kingdom of Granada), which mainly includes inventories of goods and witness statements from 1492 to 1833 , only three variants occur, despite the fact that forms of address are very frequent: vusted, usted, osted (the latter is more specifically related to the Andalusian variety). The corpus clearly confirms the close connection of these reduced variants to orality-based texts (witness statements), while literacy-based texts prefer vuestra merced or its abbreviations. The author concludes that the rich polymorphism of usted (Table 2) is a property of literary texts that cannot be extrapolated to language in general.

In view of the data in 7.2, we might however consider also the hypothesis that official texts such as those included in García-Godoy's corpus tend to standardization, in the sense of using less variants than, e.g., those used in dialects. In other words, there is not necessarily a prescriptive norm at work, but this type of text tends to reduce variation, while literary texts display the opposite tendency. It must have been almost impossible for the scribes to phonetically transcribe the dialects used by the witnesses, the same as would be the case today. This confirms the hypothesis that the standardization of usted was particularly favored in texts provided by the administration. By contrast, theatre plays might have used the existing geolinguistic and sociolinguistic variation as a reference, not refraining from playfully creating additional variants.

\section{Morphological, syntactic, and pragmatic inheritance}

This chapter provides morphological, syntactic, and pragmatic evidence for the inheritance of properties that formerly belonged to vós/vos. The fact that vossa mercê/ vuestra merced follow vós/vos, inheriting some of their features, is crucial when we try to explain their spread and generalization. According to Eberenz (2000, p. 13), vuestra merced was often a simple "extension" of vos in certain situations.

\footnotetext{
3 "Normative" has to be taken in a broad sense, not simply prescriptive, including relevant types of text, models, discourse traditions, etc.
} 


\subsection{Morphological and syntactic inheritance}

In the first place, the word structures of both Pt. vossa mercê and Sp. vuestra merced contain the second person plural possessive vossa/vuestra. They thereby belong to the same morphological paradigm as vós/vos. Second, the syntactic and morphological development of Sp. vuestra merced can be summarized as follows (see HAMMERMÜLLER, 2010, p. 522; see also BERMEJO, in print):

(6a) ¿Vos cantais, vuestra merced?

Do you sing, your Grace?

(6b) > iVuestra merced, vos cantais?

(6c) > ¿Vuestra merced, cantais?

(6d) > ¿Vuestra merced canta?

(6e) > iVuesa merced canta?

(6f) > ¿Usted canta?

Vuestra merced starts to be used as a nominal form included in the respectful address of vos, coming close to a title used as a respectful apposition. It was thus integrated in sentences where vos was used as a subject pronoun (6a,b). Hence, vos and vuestra merced formed part of the same addressing paradigm (cf. DE JONGE; NIEUWENHUIJSEN, 2009, p. 1637-1638). Consequently, the verb adopted the second person plural forms. Topicalization $(6 \mathrm{~b}, \mathrm{c})$ could place the nominal form of address in sentence initial position. The fact that Spanish is a pro-drop language favored the subsequent development from apposition to subject because the overt usage of vos was not required. In a first stage, the use of vuestra merced as subject did not affect the use of the second person plural forms of the verb, but the verb started to agree with the subject. Being used to address a single person, the subject was progressively perceived as a singular form. In present-day Spanish, agreement in the third person singular is exclusive in all standardized varieties of Spanish, but single varieties may show remnants of the second person plural forms, e.g., in some Andalusian areas.

Obviously, seen this way, there is no functional linguistic explanation as to why the pattern "vuestra merced + 2nd person plural agreement" should have developed to "vuestra merced + 3rd person singular agreement”. Bermejo (in print) follows the traditional theory of topics developing to subject, starting thereby to control dependent units in the sentence. It should not be overlooked, however, that nouns used for address are not sim- 
ple topics converted into subjects (unlike, e.g., in Brazilian Portuguese, where sentences such as the following one are used: O sujeito, ele vem primeiro/O sujeito vem primeiro 'The (grammatical) subject comes in first place'). Pragmatically speaking, forms of address always directly address a second person (see HAMMERMÜLLER, in print). This does not change if directness is mitigated by using 3rd person forms (e.g., Engl. Sir) or plurals (e.g., Sp. vos). The examples in (6c,d) show that vuestra merced could combine with 2 nd person plural, and if we take Latin, where $t u$ was the default pronoun, maiestas tua, pietas tua, clementia tua were naturally used (KOCH, 2008, p. 60). In Andalusia, ustedes combines with 2 nd or 3 rd person plural verb forms, according to the local variety. In other words, in the domain of address it does not go without saying that a nominal subject entails third person agreement, nor does a pronoun such as vos, if used to address a single person, take singular forms of the verb. Consequently, the explanation has to be retrieved in the specific diachrony of vuestra merced, especially its use in non-subject positions, and, possibly, the intervention of pragmatic advantages related to $3 \mathrm{rd}$ person indirectness.

I am tempted to introduce a remark on the present-day perception of the pronouns here. European linguists, myself included, still tend to consider Sp. vos as a second person plural pronoun. They thus refer to the original grammatical status of the pronoun. I have been criticized more than once for alluding to this origin by American linguists, who argue that it is just a second person pronoun, the same as tú. This reflects a different conscience, more schoolish in the case of linguists from Europe, closer to real "pragmatic" usage in the case of linguists from America, which is even justified regarding to the 15 th/16th centuries, where the singular function already prevailed. In the same vein, the Brazilian linguist Rumeu (in print), shows herself surprised as she discovers that in her data "second person" Pt. você correlates with third person accusative $o / a$, not with the - from her point of view - expectable second person pronoun te. This would be as if a Spanish linguist wondered why a usted le/lo veo 'I see you,' is used and not a "more expectable" but completely unusual * a usted te veo. In fact, in Spanish, usted is still seen as a third person pronoun used for second person address. Possibly, the same could be said for the European Portuguese perception of você in contrast to Brazilian Portuguese, but this would need to be tested. The fact that the subjective perception of these pronouns is so radically different on both sides of the Atlantic is an important aspect that tends to be overlooked because the pronouns are the same.

For Hammermüller (2010, p. 517-520), the reason for the establishment of "vuestra merced + 3rd person singular agreement" was the general boom of title type nominal 
forms of address between the 14th and the 16th centuries. These nominals were used not only for direct address but also as simple arguments of the verb (subject, object). This favored their perception as third person forms used for address, also used with article ("la vuestra merced”. lit. 'the Your Grace'; DE JONGE; NIEUWENHUIJSEN, 2009, p. 1638). But this explanation is more suggestive than fully convincing.

In fact, we have to take a step back and look at the diachrony of vuestra merced. According to Koch (2008), the pattern "possessive + honorific" belongs to a Latin discourse tradition going back to the diplomatic style of letters that were directed to high status persons who merited the use of an honorific noun as a face-flattering supplement to simply respectful vos. By the end of the 13th century, Spanish calked this tradition using the complement a vuestra merced, just as Lat. ad vestram gratiam was used in official contemporary documents (KOCH, 2008, p. 6-69; CAMPOS, 2002, p. 478; see also RECUERO, 2008, p. 1878 on the 15th century). Hints for a similar "third-person-origin" and "memory" of Pt. vossa mercê are provided by Marcotulio (2015).

Possibly, linguistic correction also played in favor of third person agreement, at least in the period of purification and standardization, from the 17th to the 19th century (cf. CAMPOS, 2019). The least one can say is that our concept of modern standard hardly tolerates vacillating agreement, e.g., Sp. vuestra merced with optional second or third person agreement, as was long the case (CAMPOS, 2019; BERMEJO, 2012). In European standard Portuguese, the agreement of vocês (subject) with vos or thes (complement) is a remnant of this tradition. Despite such exceptions, we must assume that, in terms of a general tendency, standardization favored systematic and coherent agreement. This tendency acted in favor of third person agreement. The case of Pt. vocês-vos agreement is therefore seen as an incoherence.

These nominal formulae were not used as full forms of address in subject position but as nouns fully integrated in ordinary syntax, e.g., as complements, albeit with honorific semantics. Vuestra merced was initially only used to address the king, together with vos (see details in RECUERO, 2008, p. 1871). According to this function, the nominals were perceived as $3 \mathrm{rd}$ person units that were syntactically dominated by vos and the corresponding verb forms. It seems that the pattern "vuestra + honorific" simply recovered its traditional perception as a third person noun as it replaced vos as a form of address in subject position.

During the 15 th century, the pattern "vuestra + honorific" was abundantly used. As a consequence of this boom, shortened variants appeared. In the long run, vuestra merced 
underwent a grammaticalization process from nominal to pronoun, including morphological and phonetic reduction. This reduction may be considered a long-term inheritance of pronominality insofar as vos diachronically disappeared (Peninsular Spanish) or lost its function as a respectful form of address, becoming an equivalent to standard Peninsular Spanish tú (America). Obviously, all these stages have to be analyzed in terms of subsequent layerings going hand in hand with parallel coexistence (compare the geolinguistic data in 7.2). Before usted definitively replaced vuestra merced, both forms coexisted in terms of functional differentiation: vuestra merced was more respectful than usted. This fact might have regionally favored the default status of usted as the less formal variant, that is, a good candidate for default address.

In the Portuguese language, the development probably followed very much the same cline, even if for the moment this process has not been empirically documented. Unlike Spanish, vós can still be found in present-day rural dialects of Northern Portugal (HAMMERMÜLLER, 1993), while it has completely disappeared from the Brazilian varieties. This is the reason why the use of address is less complex in Brazil than in American Spanish, at least if we only consider the pronouns. The main issue is the rise of você in Brazil, while this pronoun is only marginally used in Portugal.

While in Spain vos was completely lost during the 17 th century, it was commonly used in American Spanish, in paradigmatic opposition to vuestra merced > usted. According to Matthieu (1982, p. 618-619), vos and vuestra merced were used as equivalents during the first decades of colonization. In the same vein, Recuero (2008, p. 1883) refers to the mixing of the paradigms of vos and vuestra merced in the 15th and the beginning of the 16th century. This mixture explains why American Spanish has developed different paradigms in its geolinguistic variation. At that time, Pt. vós had already lost the competition with vossa mercê (and tu).

Since Sp. tú was at best conserved in familiar in-group communication, American Spanish vos tended to be used as a rather informal form of address in public communication, in contrast to respectful vuestra merced > usted. By contrast, in Spain respectful vuestra merced > usted was opposed to tú. The situation in America became rather complicated, tending to produce geolinguistic varieties, because tú was progressively implemented by colonial pressure and, later, by schooling. Consequently, vos turned out to be the vulgar informal alternative to educated informal tú, if there was no subsequent national (Argentina, since the end of the 19th century) or regional pressure (e.g., in present-day 
Andean zones of Colombia (COLLAZOS, 2015), or the area of Cartago in Costa Rica (SCHMÖLZER, 2018) which promoted the traditional form vos to the detriment of the colonial and schoolish tú or standard usted.

\subsection{Pragmatic inheritance}

There are also some hints that point to the inheritance of pragmatic features from vós/vos to você/usted.

The present-day pattern "usted of tenderness and respect" (see Section 2) presents some analogy to prior pragmatic functions of respectful address. The following refers to Portuguese, but it shows that respect in intimacy was a possible pattern. Cintra (1972, p. 66) refers to the respectful use of Pt. vós between wife and husband:

\footnotetext{
Entre amigos ou amigas de idade e de condição social próximas ou idênticas com certeza se usava regularmente o tratamento por $t u$ (o que estabelece um curioso contraste como o tratamento por vós entre marido e mulher).
}

Friends of the same age and social status regularly used mutual tu (which creates a strange contrast with vós used between husband and wife).

If the pattern is asymmetric, as in the case of children addressing their parents with vós while the parents use $t u$, the function is "respect + distance (authority)". By contrast, symmetric vós between husband and wife reduces this combination of features to "respect”. In fact, in her study on Old Portuguese, Luz (1958-1959, p. 224, 241) cites a case of a couple which changed from tu to vós after marriage (7), as well as a case of "vós of annoyance" between persons who normally used $t u(8)$ :

(6) Senhora minha: grande desdita foi haver-vos tomado por mulher.

(Trancoso, Histórias, p. 192)

My Senhora: what a wretchedness having taken you as my wife.

(7) Vós e vosso pai, que almas!

(Chiado, Compadres, p. 108)

You and your father, what souls you are!

While (8) is a situational switch, (7) reflects a systematic change reflecting a new social status. According to its context, the example in (7) does not convey tenderness, 
but simple respect. Thus, in modern European Portuguese, você may convey the same situational effect as vós in (8).

As for Spanish, the pattern "usted of annoyance" could formerly be expressed with vos. This recalls the prior use of "vos de enojo", which still exists in present-day Chilean Spanish. Conceição and Marcotullio (2011, p. 232) quote a Brazilian example from the 18th century, where the author of a letter switches from $t u$ to você in order to increase personal distance when he starts complaining about something. Hence, even if present-day Brazilian Portuguese has lost this pattern, it had existed in the past. In European Portuguese, the pattern is still known (HUMMEL, in print).

\section{Diachronic reconstruction}

Traditional diachrony would now analyze the consequences of the replacement of vós/vos in the subject position by vossa mercê/vuestra merced on the use of related subordinate syntactic units. The subjects vossa mercê/vuestra merced thus progressively entail 3rd person singular agreement on oblique pronouns (see examples in 7.1) and the use of prepositions with subject pronouns (e.g. Pt. a/para você instead of pronominal Pt. te/lhe (dative pronouns: 2nd p.sg./3rd p.sg.)). Studies on Brazilian Portuguese (e.g., RUMEU, in print, and its bibliography) and on Spanish (e.g., BERMEJO, 2018) indeed show different degrees of penetration into these syntactic domains, as well as impressive geolinguistic variation and situational variation. In the following, I will adopt another approach. Instead of diachronically following the development in texts (downstream diachrony), I will use two contemporary dialect studies for diachronic reconstruction (upstream diachrony). I will show that such data help to better understand the diachrony, in particular because we thereby use data from spoken language, putting the question of how might the oral diachrony have been.

\subsection{Oblique pronoun inheritance in Southern Portugal and Andalusia}

As shown in Section 6, the use of vuestra merced / vossa mercê and their pronominal successors usted/você in the subject position engaged a process that made the sentence be governed by the new third person form of address. This process also affected the other candidates for agreement: direct object, indirect object, reflexives, and possessives. This diachronic process can be roughly illustrated by the following stages concerning the plural forms (BERMEJO, in print): 
Table 3. Agreement penetration in diachrony (reconstruction).

I. Sp. Ustedes no os disteis cuenta de cuándo os vieron mientras caminabais

Pt. Vocês não vos destes conta de quando vos viram enquanto camináveis

You were not aware of when they saw you while you were walking

II. Sp. Ustedes no se disteis cuenta de cuándo os vieron mientras caminabais

Pt. Vocês não se disteis conta de quando vos viram enquanto camináveis

III: Sp. Ustedes no se disteis cuenta de cuándo los vieron mientras caminabais

Pt. -----

IV. Sp. Ustedes no se disteis cuenta de cuándo los vieron mientras caminaban

Pt. $\quad$----

V: Sp. Ustedes no se dieron cuenta de cuándo los vieron mientras caminaban

Pt. Vocês não se deram conta de quando os viram enquanto caminávam

According to this schematic representation of diachrony, the use of ustedes/vocês first impacted on the reflexive pronouns (Sp. os $>$ se, Pt. vos $>s e$ ) (stage I), then on the accusative (Sp. os > los; (European) Pt. conserves both, vos and os) (stage II). Since the morphological identity of Sp. os and Pt. os might cause confusion for readers, it is noteworthy that $\mathrm{Sp}$. os is equivalent to Pt. vos (2nd person plural accusative), and Sp. los to Pt. os (3rd person plural). In the final stage (V), all verbs and pronouns agree with the third person subject. This ideal path does not exclude coexisting stages in present-day synchrony. Thus, unlike its Brazilian counterpart, European Portuguese has conserved both third person os and second person vos. While this reflects a conservative tendency, the replacement of second by third person verb forms has been much faster. In Spanish, the competition between second and third person verb form has produced different results in the present-day geolinguistic varieties.

The progressive replacement of the 2 nd person forms by the 3 rd person forms can be accessed in terms of diachronic reconstruction from present-day geolinguistic variation. The fine-tuned study of the plural forms ustedes/vocês by Bermejo (in print) in Southern Portugal (Map 1) and Andalusia (Map 2) provides the following result: 
Map 1. Current geographical extension of the levelling in vocês.

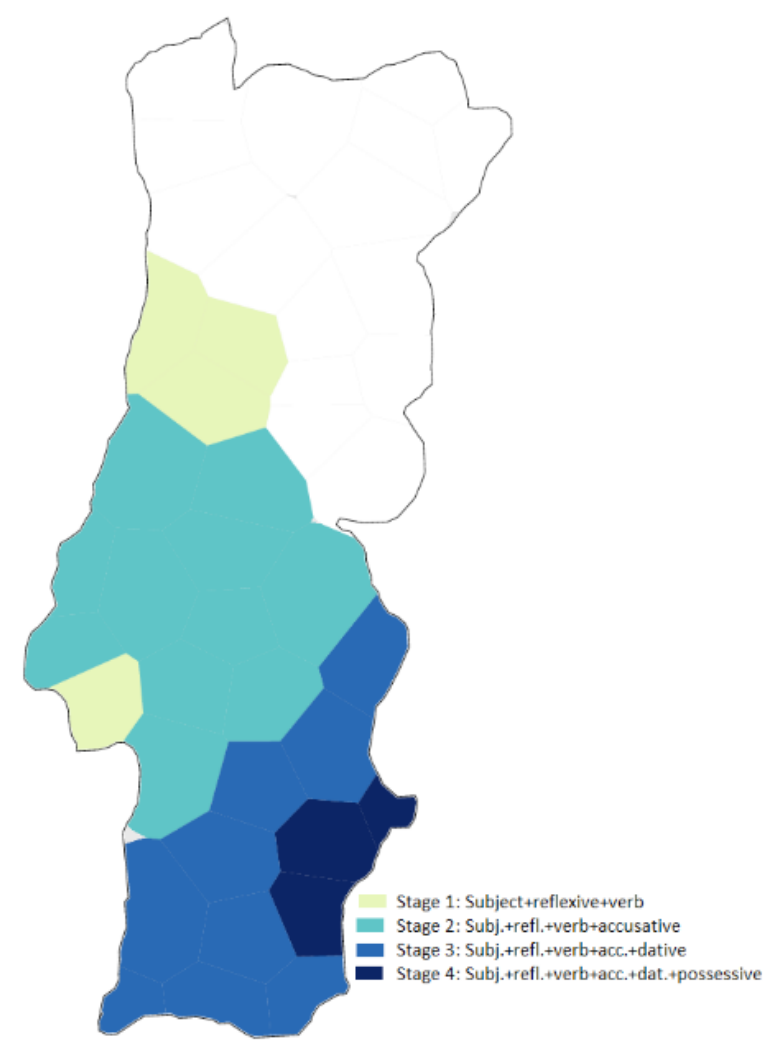

The present-day geolinguistic distribution provides evidence for the southern areas being more progressive than the northern ones.

As for Andalusia, Bermejo's data show the same type of progression from North to South. Map 2 shows the current geographical extension of agreement with ustedes in Andalusia:

Map 2. Current geographical extension of the agreement with ustedes.

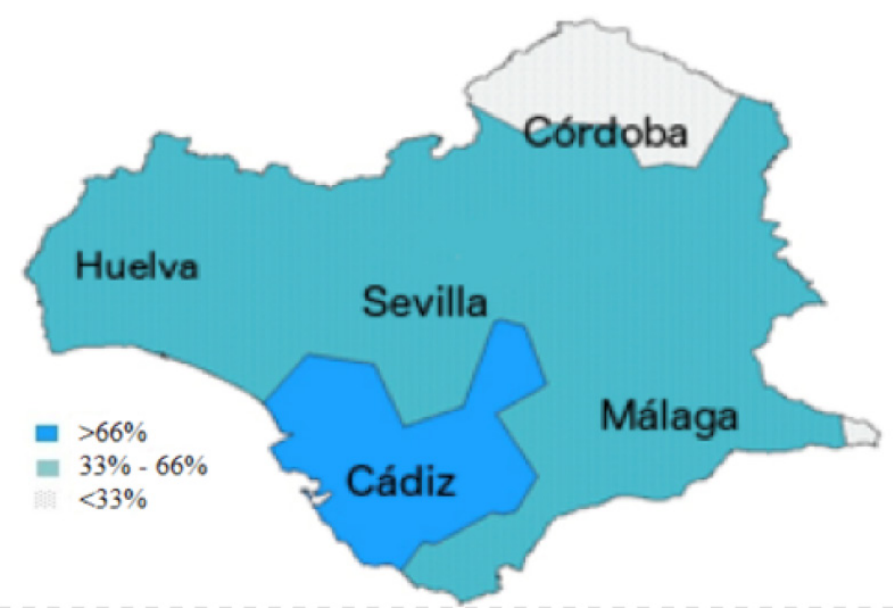


In this case, the dialect data from the ALPI (Atlas Lingüístico de la Península Ibérica) allow a comparison of the already simplified present-day variation with the situation in the first half of the 20th century:

Map 3. ALPI's geographical and grammatical extension of the levelling in ustedes.

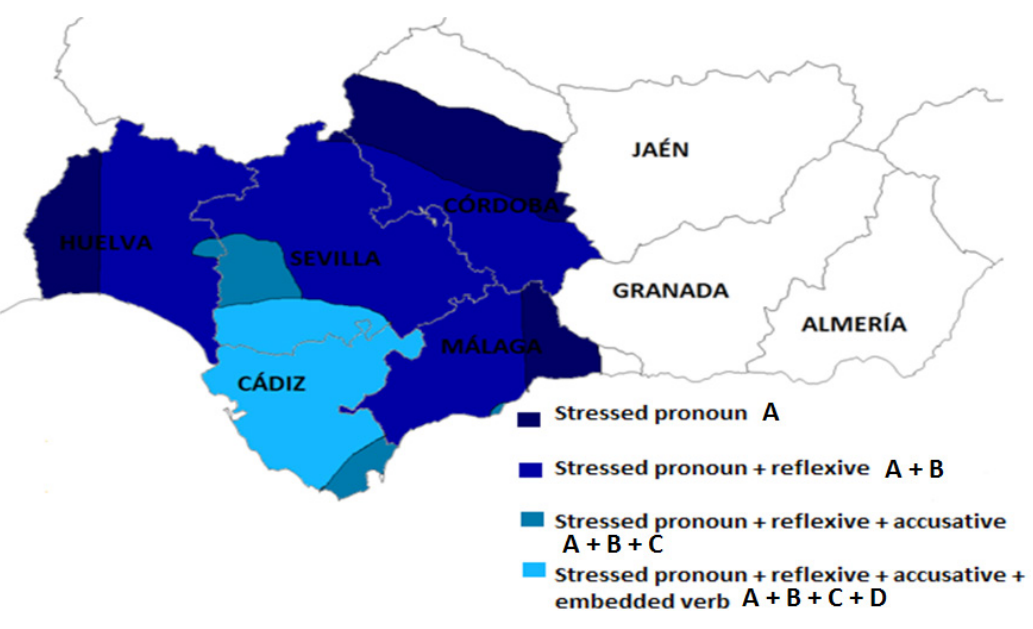

Without going into details, the differentiated analysis of agreement inheritance clearly displays the same dynamics as in Southern Portugal. This is one of the reasons why Bermejo claims the existence of a south-western Sprachbund, that is, an area where two different languages share relevant linguistic features for real reasons. While it is questionable whether "Portuguese" and "Spanish" could be considered as clearly different languages in their oral and literate beginnings, the underlying idea of area driven geolinguistic cohesion is certainly a valid one.

The data in Table 3 is a diachronic reconstruction based on the present-day data in Maps 1,2, and 3. This is the reason why the reconstructed diachronic stages are annotated differently (stages I to V). For details see Bermejo (in print).

Given the progressive tendencies in the south-west of the Iberian Peninsula, it comes as no surprise that American Spanish shows crucial similarities with this area, e.g., the (almost) exclusive use of Sp. ustedes, or the loss of Pt. vós/vos in Brazilian Portuguese. On the other hand, the widespread conservation of vos in American Spanish shows that American Spanish is not the continuation of what happened in Andalusia, but a development of its own that started out of the same historical basis. By contrast, the generalized usage of ustedes as the only plural pronominal form of address in American Spanish can indeed be situated in line with the progressive Andalusian development. American Spanish thus suggests the hypothesis that the replacement of vos by usted/ustedes has 
been faster with the plural form. In fact, in the 15th century, vos had almost lost its original plural function. In Spain, plural vos has been replaced by vosotros (informal) and the predecessors of ustedes (formal).

Unlike what happened in Spain, vosotros did not reach America to a significant degree, at least as far as the direct oral tradition is concerned. Its first European Spanish attestation dates from the 15th century (HAMMERMÜLLER, 2010, p. 515). In his study on the diachrony of address in Costa Rica, Quesada Pacheco (2010, p. 658-659) finds no use of vosotros, and de Jonge and Nieuwenhuijsen (2009, p. 1652) find only marginal use in the period from 1500 to 1600 in America (see also CAMPOS, 2019, p. 132-134 and BERTOLOTTI, 2018). Such marginal use can easily be explained by colonial influence from Europe and the general restrictions operating at that time on the use of vosotros. This pronoun only surfaces later, after the national independence, in highly formal and formulaic texts. This description can be extended to Hispanic America in general (see DANKEL; GUTIÉRREZ MATÉ, in print). Interestingly, Fernández Martín (2012) observes that vosotros was marginal and marked in 18th century Andalusia, where ustedes was more clearly preferred than in Madrid. In line with this, Campos (2015) finds that between 1492 and 1833 in the Kingdom of Granada the use of vosotros was secondary and highly marked for specific situations, vuestras mercedes being the preferred form for simply expressing respect. While vosotros was used in asymmetric relations, the plural vuestra merced conveyed respect in asymmetric and symmetric relations, even inside families (CAMPOS, 2019, p. 130-131). Consequently, the inheritance of agreement analyzed by Bermejo can be related to a preference for the use of ustedes. It is noteworthy that Fernández Martín's data stem from Cádiz, which is the most progressive area in Maps 2 and 3. As for the simplification hypothesis, which analyzes the loss of vosotros as a paradigmatic simplification in the context of linguistic restructuration, I agree with Campos (2019, p. 139-142) who rejects this hypothesis. Nor is simplification a general tendency of American Spanish, particularly not in the domain under scrutiny (cf. the persistence of vos and the rich geolinguistic variation), but also because address is too sensitive to personal and sociolinguistic factors. Thus, simplification caused by intra-linguistic factors is highly improbable. This domain only simplifies as social relations simplify (BROWN; GILMAN, 1960). In sum, it seems that the loss of vosotros was rather expectable in view of its restricted use, even in the Iberian Peninsula. As pointed out by Campos (2019), we should rather explain how it has lost these restrictions in Spain. Section 7.2 provides another case where it is not America but Europa that drifts apart.

It should be noted that for Bermejo (in print) and others (see bibliography in 
Bermejo), vosotros reached America as a fully established pronoun. Consequently, its elimination is seen as a subsequent process. Even if there is evidence for this in American Spanish documents, this does not necessarily include the genuine oral tradition. From the point of view of reconstruction, the use of vosotros in the broad sense of Plural 'you', that is, not restricted to exclusive 'you others', seems to have been at best marginal, possibly also in the south-western Sprachbund (see previous paragraph). I freely admit that this is necessarily speculative, but the evidence from written sources is probably also biased by factors such as written language and official preference. Why should America have lost fully established vosotros, while it behaves conservative in most domains? Obviously, the loss could also be related to the progressive restriction of vos to a 2 nd person singular pronoun, while at the same time vos came out of use in Spain. This process would indeed be posterior to the 15 th century. However, the recent analysis and synthesis of this topic by Bertolotti (in print) confirms that vosotros is likely not to have reached significant use in America, and this from the very beginnings. Empirical studies on Andalusia (CAMPOS, 2015; FERNÁNDEZ MARTÍN, 2012) and data from America (DEJONGE; NIEUWENHUIJSEN, 2009; BERTOLOTTI, in print) converge at this point.

This does not explain, however, why vosotros did not reach America to a significant degree. The only explanation is that it was not used in the spoken language of most of the men who set out to colonize America. It is noteworthy, in this context, that the whole south-western Sprachbund prefers the plurals Sp. ustedes and Pt. vocês. In Portuguese, the former plural function of vós has not been replaced by a morphological equivalent to Sp. vosotros. Vocês filled this gap. The same happened in major parts of Andalusia. Hence, there is converging evidence for preferring these forms in the south-western Sprachbund. Linguistic contact on the way to America could be another factor. The relevance of Portuguese in commercial places is a well-known fact, and, if we do not restrict our analysis to usted/você, we must admit that the variants, e.g., Sp. vuesa merce(d) and Pt. vossa mercê, are phonetically close enough in spoken language to have been favored by linguistic contact in a shared cultural context. In other words, we need not provide more explanation than in similar cases. It is a simple matter of selection. Some varieties of Spanish, the progressive varieties, have selected vuestras mercedes to the detriment of vosotros.

\subsection{Você and its variants in the geolinguistic variation of contemporary Portugal}

All the evidence and conjectures referred to in 7.1 cannot explain how the pronouns você(s) and usted(es), which in this spelling are first attested by the end of the 
16th century, not only reached America but deeply rooted there, often as the default form of address, at least in the public domain.

For de Jonge and Nieuwenhuijsen (2009, p. 1651-1652; cf. BERTOLOTTI, 2015, p. 132-135), the absence of vosotros in colonial America is still an "intriguing" question because (i) it was firmly rooted in Spain by the end of the 15 th century and (ii) because the replacement by usted was not possible before the end of the 17th century when usted/ ustedes first appeared. While (i) has been answered in 7.1, the principle objection against (ii) is not the earlier attestation of usted, already in the 16th century, but the fact that we cannot take the use of usted/ustedes as the starting point. All available data clearly confirm, for both Spanish and Portuguese, that not only the singular vuestra merced/vossa mercê but also the plural vuestras mercedes/vossas mercês were well established in the spoken language of the 16th century (see also 7.1). The plural vuestras mercedes had started to be used by the end of the 15th century (CAMPOS, 2019, p. 127). Now, it is hard to imagine that the singular forms produced a wide array of variants while the plural ones should not have. This makes no sense. Both underwent the same grammaticalization process. Consequently, the fact that the form ustedes as such, in this orthographic spelling, appeared too late to explain the substitution is not a valid argument since the predecessors of ustedes were available and largely used.

I will now try to deepen this topic from the point of view of reconstruction with contemporary dialect data from Portugal.

If we only bear in mind modern standard European Spanish and Portuguese, the generalization of Sp. usted in America is surprising, and that of você in Brazil comes close to a wonder. Both came up as late as the end of the 16th century. Although in Spain the use of usted is currently perceived as extremely formal - a fact that entails marginalization - it can be considered as firmly established as the standard form of respectful address if we look back to diachrony. By contrast, in present-day standard European Portuguese, the use of você is marginal and often negatively connoted, and this fact does not significantly change in the diachronic perspective.

The Portuguese dialectologist Paiva Boléo and his students gathered an impressive quantity of information on Portugal's dialects between 1942 and 1974 called Inquérito Linguístico Boléo (ILB), which remains unpublished but is still hosted at the University of Coimbra. This unique treasure consists of approximately 3,100 Inquéritos (questionnaires) and 1,800 Relatórios (reports). The first edition of the Inquéritos contains the answers to 550 questions; the number of questions was later extended to 757 . In addition, the students were asked to provide a personal account of their observations, the 
so-called relatórios. The data covered the whole territory of Portugal as well as the islands of Madeira and the Azores. The ILB remains largely unexplored up to the present, but Hammermüller (in print) has analyzed the data concerning você; that is, the amazing number of phonetic variants that stem from original vossa mercê.

Table 4 provides a geolinguistic overview of these data. The structure of the table reflects Portugal's rectangular geography, from North to South (1-9) and from West to East, adding the Azores and Madeira islands at the end (9). The preferred variants are in italics:

Table 4. Common forms of address in the districts of Portugal.

\begin{tabular}{|c|c|c|c|}
\hline $\begin{array}{l}\text { North (1) } \\
\text { to South (8) } \\
\text { plus islands (9) }\end{array}$ & West & Middle & East \\
\hline 1 & 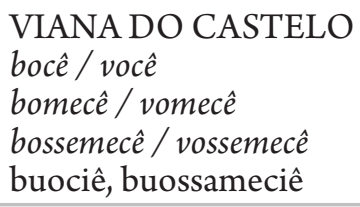 & & $\begin{array}{l}\text { BRAGANÇA } \\
\text { bocî / vocêe } \\
\text { bomecề / vomecê } \\
\text { bossemecê / vossemecề } \\
\text { bacê, bancê, boncê, bõucê }\end{array}$ \\
\hline 2 & $\begin{array}{l}\text { PORTO } \\
\text { bocê / vociê } \\
\text { bomecê / vomecê } \\
\text { bossemecê / vossemecê } \\
\text { bòcê } \\
\text { bòmeciê }\end{array}$ & $\begin{array}{l}\text { BRAGA } \\
\text { bocê / vocie } \\
\text { bomecêe / vomecề } \\
\text { bossemecê / vossemecê } \\
\text { bòcê } \\
\text { bòsjề }\end{array}$ & $\begin{array}{l}\text { VILA REAL } \\
\text { bocêe / você } \\
\text { bomecề / vomecề } \\
\text { bossemecê / vossemecê } \\
\text { bocia } \\
\text { boncê, vancê }\end{array}$ \\
\hline 3 & $\begin{array}{l}\text { AVEIRO } \\
\text { bocê / vocie } \\
\text { bomecê / vomecie } \\
\text { bossemecê / vossemecê } \\
\text { bocêê, boceia } \\
\text { bocemecê }[=\text { bossemecê] } \\
\text { <bwòsnề }{ }^{*}\end{array}$ & $\begin{array}{l}\text { VISEU } \\
\text { bocê / você } \\
\text { bomecê / vomecêe } \\
\text { bossemecê / vossemecê } \\
\text { bomcê }[<\text { bomecề }]\end{array}$ & $\begin{array}{l}\text { GUARDA } \\
\text { bocî / você } \\
\text { bomeccê / vomeciê } \\
\text { bossemecê / vossemecie } \\
\text { bòcê }\end{array}$ \\
\hline 4 & $\begin{array}{l}\text { COIMBRA } \\
\text { bocê / você } \\
\text { bomecề / vomecê } \\
\text { bossemecê / vossemecê } \\
\text { bacê } \\
\text { bocềs - bocêses } \\
\text { [= plural-extension] } \\
\text { bomecê, bomcê } \\
\text { vancê (Penacova) }\end{array}$ & & \\
\hline 5 & $\begin{array}{l}\text { LEIRIA } \\
\text { bocê / você } \\
\text { bomecê / vomecî } \\
\text { bossemecê / vossemecê } \\
\text { bacé }\end{array}$ & & $\begin{array}{l}\text { CASTELO BRANCO } \\
\text { bocê / você } \\
\text { bomecê / vomecê } \\
\text { bossemecê / vossemecê } \\
\text { bocé } \\
\text { bossemecê } \\
\text { vom'cê [< vomecê] } \\
\text { vomessaj, vomessaji } \\
\text { vossaj, vossaji } \\
\text { vossamecé } \\
\text { vossemecéj, vossemessöj } \\
\text { vossomecê }\end{array}$ \\
\hline
\end{tabular}




\begin{tabular}{|c|c|c|c|}
\hline 6 & $\begin{array}{l}\text { LISBOA } \\
\text { bocê / você } \\
\text { bomecê / vomecê } \\
\text { bossemecê / vossemecê }\end{array}$ & $\begin{array}{l}\text { SANTARÉM } \\
\text { vocêe } \\
\text { vomecêe } \\
\text { vossemecê } \\
\text { vossemecê } \\
\text { vomcêj } \\
\text { vossemecêj }\end{array}$ & 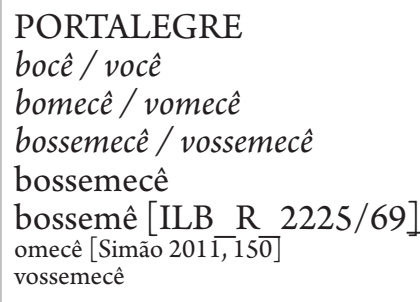 \\
\hline 7 & $\begin{array}{l}\text { SETÚBAL } \\
\text { bocêe / vocêe } \\
\text { bomecê / vomecê } \\
\text { bossemecê / vossemecê } \\
\text { bocei - vocêí } \\
\text { vossemecêia }\end{array}$ & $\begin{array}{l}\text { ÉVORA } \\
\text { você } \\
\text { vomecêe } \\
\text { vossemecê } \\
\text { vossemecej } \\
\text { vossemeceia }\end{array}$ & $\begin{array}{l}\text { BEJA } \\
\text { você } \\
\text { vomeche } \\
\text { vossemecê } \\
\text { vomecea } \\
\text { vossemecea, vossemeceia }\end{array}$ \\
\hline 8 & & $\begin{array}{l}\text { FARO } \\
\text { você, vomecê, vossemecê } \\
\text { abeceia, amecêa } \\
\text { vocêa } \\
\text { vomeceia } \\
\text { vòssemecêa } \\
\text { voumecê }\end{array}$ & \\
\hline 9 & AÇORES (Horta) vomecêa & & MADEIRA --- \\
\hline
\end{tabular}

Table 4 provides striking evidence for the generalized use of variants that are genetically related to você. In the first place, the obvious predecessors of você, mostly vossemecê, are followers of the original form vossa mercê 'Your Grace'. In terms of diachronic reconstruction, this proves that vossa mercê had once been the general form of respectful address over the whole European territory of Portugal. Secondly, the dialect data further shows that vossa mercê was used in spoken language, which is the reason why there are so many phonetic variants, including processes of "erosion", with você as one of the reduced variants.

If we bear in mind that American Portuguese was profoundly driven by the spoken language of the Portuguese colonists, we now easily understand what happened: the relevant fact is that a large array of spoken variants of vossa mercê, which is the written spelling, came to America. The ILB data further suggest that these variants were the most commonly used form for respectful address. Hence, we need no longer formulate the question of how você came to Brazil. The firm establishment of variants situated between vossa mercê > você was the most likely diachronic development. In other words, it was not America that drifted apart from the diachronic origins, but instead standard European Portuguese, whose drifting apart was, however, not followed by the European Portuguese dialects, as shown by the ILB. In other words, present-day Brazil is in line with the situa- 
tion reflected by Table 4 . This is one more example of the usual, but misleading, intuitive approach to American Spanish and Portuguese, which perceives the New World varieties as deviations from the metropolitan language. At first glance, this is intuitively plausible inasmuch as Portugal and Spain are the areas where the American varieties stem from. However, the European varieties may well have drifted apart from their origins more so than the American varieties. Consequently, the question as to which variety has drifted away should be treated as an open question to be answered with adequate empirical data. In the case under scrutiny, the contemporary geolinguistic variation in 20th century Portugal shows that Brazil has simply conserved the former "rural standard".

All this means that the really interesting question is that of why and how você has gained its marginal and often negatively connoted status in European Portuguese. Diachronic reconstruction does not always provide sufficient evidence for diachrony. Its main function may even be considered as a methodology that allows the formulation of questions and hypotheses meant to guide traditional diachronic research. In this case, the fact that the variants of vossa mercê were used all over the Portuguese territory as late as in the 20th century suggests the hypothesis that the modern standard of address in European Portuguese is an urban phenomenon. In his manual on Brazilian Portuguese, Noll (2008, passim) repeatedly attributes differences to European Portuguese to changes in Europe (not Brazil!) driven by the capital Lisbon. Indeed, a widespread saying goes "Você é estrubaria" 'você is crap', with clear rural connotation to dung and stable (HAMMERMÜLLER, 1980). Hence, the negative connotation of European Portuguese você seems to derive from urban standardization moving away from rural usage. The latter is exactly the usage that won the competition in American Portuguese.

Faraco (2017, p. 121) and, referring to him, Bermejo (in print) see the development the other way round: você as an urban upper class phenomenon which therefore would have been negatively perceived in the countryside (they mention "estrubaria"). It is hard to understand, however, how the dung-connoted saying Você é estrubaria could have referred to an upper-class behavior. The following citation commenting on this saying, from a linguist who knows Portugal's dialect landscape particularly well, is more convincing:

As original sources for those statements we may imagine, among others, primary school teachers and clergymen ("their master's voice") who were influenced by their own experience and pedagogical studies in urban 
centers (mostly oriented towards the standards of Lisbon/Coimbra/ Porto) (HAMMERMÜLLER, in print).

This means that "você é estrubaria" reflects what the educated told the rural population. But the origin of the saying is a secondary point. Table 4 shows that the use of você is firmly established in rural zones. A simple imitation from a high prestige variety would scarcely have reached all the rural areas, nor, and most importantly, could the diffusion of already lexicalized upper class você have produced the large array of attested phonetic variants. In addition, the maps referring to the geolinguistic distribution of $t u / v o c \hat{e}$ in Brazil (see LOPES et al., in print) consistently show that você prevails in the interior of Brazil, while $t u$ is more prominent along the coast. This is a clear indicator of later colonial pressure favoring $t u$ in the areas that were most likely to get in contact with the European prestige variety and, hence, for $t u$ layering over the followers of vossemecê.

I see, at best, a late European influence regarding the spread of você as the orthographic variant preferred of all spellings in Table 4. In fact, the last point to discuss now is why você is the only reduced variant of vossa mercê that has penetrated modern standard on both sides of the Atlantic Ocean. In Hummel (in print), I have been too radical in claiming that the spread of both Pt. você in Brazil and Sp. usted in American Spanish could be due to the influence of the colonial civil and military administration, where these pronouns were indeed used for respectful address (MONTE, 2015a, 2015b). As shown above, the spread of vossa mercê / vuestra merced can indeed be related to colonial pressure from above. The path via the civil and military administration has the advantage of being the only one where the late-born pronouns could have reached the whole colonial territories of Portugal and Spain. Indeed, historical documents provide evidence for this administrative colonial discourse tradition. However, this paper has shown that the spoken variants of Pt. vossa mercê and Sp. vuestra merced were already common place in public respectful communication. The civil and military administration probably simply influenced the selection of the pronunciations/spellings você/usted as the only reduced variants accepted in written standard. Hence, where grammaticalization theory sees a simple development of language (vossa mercê > você), the variationist data provides evidence for diachronic selection driven by normative forces. 


\section{Conclusion}

The geolinguistic data allow us to put an end to an apparent aporia. If we bear in mind only modern standard European languages, the generalization of Sp. usted in America is surprising, and that of você in Brazil a wonder. By contrast, the dialect data suggest that the variants of vossa mercê/você have a long and coherent tradition in genuine spoken Portuguese, and, possibly, also in Spanish. From this follows that the generalization of você in Brazil was the most likely scenario in spoken language. This process was a simple extension of what was the most usual practice in the dialects of Portugal. For the moment, we can only suppose that exactly the same happened with Spanish. However, Spanish conserved vos longer than was the case for Pt. vós. This is the reason why the diachrony of American Spanish is more complicated.

It should be added that the method of diachronic reconstruction is not free from speculation. Occasionally, the contemporary facts are clear enough to (almost) predict diachrony, but, in general, the conjectures are more or less plausible. Hence, the main function of this methodology is that of formulating questions and hypotheses for subsequent research in diachrony. This was the main purpose of this paper. This is also the reason why I have scarcely used exact diachronic dating. This should be provided by future research.

\section{References}

ALPI (Atlas Lingüístico de la Península Ibérica), www.alpi.ca.

AMPUERO, Roberto. Boleros en La Habana. Santiago: Planeta Chilena, 1998.

BENTIVOGLIO, Paola. Spanish forms of address in the sixteenth century. In: TAAVITSAINEN, Irma; JUCKER, Andreas (eds.) Diachronic perspectives on address term systems. Amsterdam \& Philadelphia: John Benjamins, 2003. p. 177-191.

BERMEJO, Víctor Lara. 'Ustedes' instead of 'vosotros' and 'vocês' instead of 'vós': an analysis through the Linguistic Atlas of the Iberian Peninsula (ALPI). Dialectologia. Special issue, v. 3, p. 57-93, 2012.

BERMEJO, Víctor Lara. Los clíticos de segunda persona de plural en las lenguas romances de la Península Ibérica. Zeitschrift für Romanische Philologie, v. 134, n. 1, p. 62-85, 2018.

BERMEJO, Víctor Lara (in print). Forms of address in the south-western Sprachbund of the Iberian Peninsula: one hundred years of evolution in western Andalusian Spanish and European Portuguese. In: HUMMEL, Martin; LOPES, Célia Regina dos Santos (eds.) (in print). Address in Portuguese and Spanish. Studies in diachrony and diachronic reconstruction. Series Topics in Address Research (TAR). Amsterdam / Philadelphia (John Benjamins). 
BERMEJO, Víctor Lara; GUILHERME, Ana. The politeness of 'você' in European Portuguese. Studies in Hispanic and Lusophone Linguistics, v. 11, n. 2, p. 337-366, 2018.

BERTOLOTTI, Virginia. La gramaticalización de 'usted': un cambio lingüístico en proceso. Evidencias en el Uruguay del siglo XIX. Filologia linguistica portuguesa, n. 12(1), p. 149-177, 2010.

BERTOLOTTI, Virginia. A mí de vos no me trata ni usted ni nadie: sistemas e historia de las formas de tratamiento en la lengua española en América. Mexico City: UNAM / Universidad de la República Uruguay, 2015.

BERTOLOTTI, Virginia. “El problema de 'vosotros””: una curiosidad del español europeo fosilizada en América. In: BOSQUE, Ignacio; COSTA, Sylvia; MALCUORI, Marisa (eds.). Palabras en lluvia minuciosa. Madrid / Frankfurt: Iberoamericana / Vervuert, 2018. p. 17-35.

BERTOLOTTI, Virginia (in print). The loss of 'vosotros' in American Spanish. In: HUMMEL, Martin; LOPES, Célia Regina dos Santos (eds.) (in print). Address in Portuguese and Spanish. Studies in diachrony and diachronic reconstruction. Series Topics in Address Research (TAR). Amsterdam / Philadelphia (John Benjamins).

BROWN, Roger; GILMAN, Albert. The pronouns of power and solidarity. In: SEBEOK, Thomas A. (ed.). Style in language. Cambridge: MIT Press, 1960. p. 253-276.

BROWN, Penelope; LEVINSON, Stephen C. Politeness. Some universals in language usage. Cambridge: Cambridge University Press, 1987.

CAMPOS, Miguel Calderón. Fórmulas de tratamiento en las cartas del Conde de Tendilla (1504-1506). In: ELIZONDO, María Teresa Echenique; MÉNDEZ, Juan Pedro Sánchez (eds.). Actas del V Congreso Internacional de Historia de la Lengua Española, 2 vols., Madrid: Gredos, 2002. p. 477-487.

CAMPOS, Miguel Calderón. El español del reino de Granada em sus documentos (14921833): oralidad y escritura. Bern: Peter Lang, 2015.

CAMPOS, Miguel Calderón. Pérdida del pronombre 'vosotros' y su paradigma. In: MÉNDEZ, Juan Pedro Sánchez; AVELEDO, Antonio Corredor; CASTILLA, Elena Padrón (eds.). Estudios de morfosintaxis histórica hispano-americana. vol. 1: El pronombre. Valencia: Tirant Humanidades, 2019. p. 125-162.

CÁRCELES, José Pla. La evolución del tratamiento 'vuestra merced', Revista de Filología Española, v. 10, p. 245-280 and 402-403, 1923.

CARRICABURO, Norma. Las fórmulas de tratamiento en el español actual. Madrid Arco Libros, 1997.

CINTRA, Luís F. Lindley. Sobre 'formas de tratamento' na língua portuguesa. Lisboa: Livros Horizonte, 1972.

COLLAZOS, Ana María Díaz. Desarrollo sociolingüístico del voseo en la región andina de Colombia (1555-1976). Berlin \& Boston: de Gruyter, 2015. 
CONCEIÇÃO, Adriana Angelita da; MARCOTULIO, Leonardo Lennertz. História e linguagem: um diálogo sobre o tratamento na prática epistolar luso-brasileira setecentista. In: COUTO, Leticia Rebollo; LOPES, Santos (eds.). Asformas de tratamento em português e em espanhol variação, mudança e funções conversacionais. Rio de Janeiro: Editora da Universidade Federal Fluminense, 2011.p. 213-242.

COUTO, Leticia Rebollo; LOPES, Célia Regina dos Santos (eds.). Asformas de tratamento em português e em espanhol. Niterói: Editora da UFF, 2011.

DANKEL, Philipp; MATÉ, Miguel Gutiérrez (in print). 'Vuestra atención, por favor' ('your attention, please'). Some remarks on the usage and history of plural 'vuestro/a' in Cusco Spanish (Peru). In: HUMMEL, Martin; LOPES, Célia Regina dos Santos (eds.) (in print). Address in Portuguese and Spanish. Studies in diachrony and diachronic reconstruction. Series Topics in Address Research (TAR). Amsterdam / Philadelphia (John Benjamins).

DE JONGE, Bob; NIEUWENHUIJSEN, Dorien. Formación del paradigma pronominal de las formas de tratamento. In: COMPANY, Concepción Company (ed.). Sintaxis histórica de la lengua española. Segunda parte: La frase nominal. Vol. 2. México D.F.: UNAM / Fondo de Cultura Económica, 2009. p. 1595-1671.

EBERENZ, Rolf. El español en el otoño de la Edad Media. Sobre el artículo y los pronombres. Madrid: Gredos, 2000.

FARACO, Carlos Alberto. O tratamento 'você' em português: uma abordagem histórica. LaborHistórico, v. 3, n. 2, p. 1-132, 2017 [1996].

GARCÍA-GODOY, María Teresa. El cambio 'vuestra merced > usted' desde la documentación archivística. In: MÉNDEZ, Juan Pedro Sánchez; TORRE, Mariela de la; CODITA, Viorica (eds.). Temas, problemas y métodos para la edición y el studio de documentos hispánicos antiguos. Valencia: Tirant Humanidades, 2015. p. 661-694.

GARCÍA-GODOY, María Teresa. ¿Fue vulgar o plebeyo el origen de 'usted'? La diacronía del pronombre de respeto desde la interfaz oral/escrito. Oralia, n. 19, 2016. p. 61-84.

HAMMERMÜLLER, Gunther. O tratamento de vós em Rio de Onor. In: SCHMIDTRADEFELDT, Jürgen (ed.), Semiótica e linguística portuguesa e românica. Tübingen: Gunter Narr, 1993. p. 43-54.

HAMMERMÜLLER, Gunther. “Você é estrubaria?”. Iberoromania, n. 12, p. 30-40, 1980.

HAMMERMÜLLER, Gunther. Evolución de las formas de tratamiento del español medieval hasta el siglo XVI. In: HUMMEL, Martin; KLUGE, Bettina; LASLOP, María Eugenia Vázquez (eds.). Formas y fórmulas de tratamiento en el mundo hispánico, México (D.F.): El Colegio de México / Karl-Franzens-Universität Graz, 2010. p. 507-529.

HAMMERMÜLLER, Gunther (in print). Retracing the historical evolution of the Portuguese address pronoun você using synchronic variationist data. In: HUMMEL, Martin; LOPES, Célia Regina dos Santos (eds.) (in print). Address in Portuguese and Spanish. Studies in diachrony and diachronic reconstruction. Series Topics in Address Research (TAR). Amsterdam / Philadelphia (John Benjamins). 
HELINCKS, Kris. Variation and discursive shifting of address forms in Chilean Spanish. Formal, socio-situational and pragmatic analysis of spontaneous conversation. $\mathrm{PhD}$ thesis, University of Gent, 2016.

HISTÓRIA dos pronomes de tratamento no português brasileiro. LaborHistórico, Rio de Janeiro, v. 1, n. 1, 2015.

HUMMEL, Martin (in print). Diachronic research on address in Portuguese and Spanish. In: HUMMEL, Martin; LOPES, Célia Regina dos Santos (eds.) (in print). Address in Portuguese and Spanish. Studies in diachrony and diachronic reconstruction. Series Topics in Address Research (TAR). Amsterdam / Philadelphia (John Benjamins).

HUMMEL, Martin; KLUGE, Bettina; LASLOP, María Eugenia Vázquez (eds.). Formas y fórmulas de tratamiento en el mundo hispánico, México (D.F.): El Colegio de México / Karl-Franzens-Universität Graz, 2010.

HUMMEL, Martin; LOPES, Célia Regina dos Santos (eds.) (in print). Address in Portuguese and Spanish. Studies in diachrony and diachronic reconstruction. Series Topics in Address Research (TAR). Amsterdam / Philadelphia (John Benjamins).

KING, Jeremy. Ceremonia y cortesía en la literature del Siglo de Oro: un estudio de las formas de tratamiento en español. In: HUMMEL, Martin; KLUGE, Bettina; LASLOP, María Eugenia Vázquez (eds.). Formas y fórmulas de tratamiento en el mundo hispánico, México (D.F.): El Colegio de México / Karl-Franzens-Universität Graz, 2010. p. 531-550.

$\mathrm{KOCH}$, Peter. Tradiciones discursivas y cambio lingüístico: el ejemplo del tratamiento 'vuestra merced' en español. In: KABATEK, Johannes (ed.). Sintaxis histórica del español y cambio lingüístico. Madrid / Frankfurt: Iberoamericana / Vervuert, 2008. p. 53-87.

LAVENDER, Jordan. 'Usted' of solidarity in Azogues, Ecuador. An analysis of data from Facebook Messenger, Linred, 2017. Available in: <www.linred.com>.

LOPES, Célia Regina dos Santos et al. Quem está do outro lado do túnel? 'Tu' e 'você' na cena urbana carioca. Neue Romania, v. 39, p. 49-66, 2009.

LOPES, Célia Regina dos Santos et al. A reorganização do sistema pronominal de 2a pessoa na história do português brasileiro: a posição de sujeito. LOPES, Célia Regina dos Santos (ed.) Mudança sintática das classes de palavra: perspectiva funcionalista. São Paulo: Contexto, 2018, p. 24-141.

LOPES, Célia Regina dos Santos et al. A reorganização do sistema pronominal de $2^{\text {a }}$ pessoa na história do português brasileiro: outras relações gramaticais. LOPES, Célia Regina dos Santos (ed.) Mudança sintática das classes de palavra: perspectiva funcionalista. São Paulo: Contexto, 2018, p. 142-185.

LOPES, Célia Regina dos Santos; MARCOTULIO, Leonardo Lennertz; OLIVEIRA, Thiago Laurentino de (in print). Forms of address from the Ibero-Romance perspective: a brief history of Brazilian 'voceamento' In: HUMMEL, Martin; LOPES, Célia Regina dos Santos (eds.) (in print). Address in Portuguese and Spanish. Studies in diachrony and diachronic reconstruction. Series Topics in Address Research (TAR). Amsterdam / Philadelphia (John Benjamins). 
LUZ, Marilina dos Santos. Fórmulas de tratamento no português arcaico. Revista Portuguesa de Filologia, v. 9, n. 1-2, p. 55-281, 1958-1959.

MARCOTULIO, Leonardo Lennertz. Sobre la génesis de 'vossa mercê' en el portugués medieval. Lingüistica, v. 31, n. 1, p. 61-79, 2015.

MARTÍN, Elisabeth Fernández. 'Vosotros/ustedes': Estudio del tratamiento plural en el español dieciochesco. In: GARCÍA-GODOY, María-Teresa (ed.). El español del siglo XVIII, Bern, etc.: Peter Lang, 2012. p. 153-194.

MATÉ, Miguel Gutiérrez. El pronombre 'usted' en el español de Cartagena de Indias del siglo XVII y su 'divergencia' de 'vuestra merced'. In: CARTELLE, Emilio Montero; ROVIRA, Carmen Manzano (eds.), Actas del VIII Congreso internacional de historia de la lengua española. Santiago de Compostela: Meubook / AHLE, 2012. p. 1889-1904.

MATHIEU, Nicolás del Castillo. Testimonios del uso de 'vuestra merced', 'vos' y 'tú' en América (1500-1650). Thesaurus 37, 1982. p. 602-644.

MICHNOVICZ, Jim; DESPAIN, J. Scott; GORHAM, Rebecca. The changing system of Costa Rica pronouns of address. In: MOYNA, María Irene; RIVERA-MILLS, Susana (eds.). Forms of address in the Spanish of the Americas. Amsterdam / Philadelphia: John Benjamins, 2016. p. 243-265.

MONTE, Vanessa Martins do. Correspondências Paulistas: as formas de tratamento em cartas de circulação pública (1765-1775). São Paulo: Fapesp, Humanitas, 2015a.

MONTE, Vanessa Martins do. A categoria socioprofissional: uma proposta de abordagem para o estudo das formas de tratamento. LaborHistórico, v. 1, n. 1, 2015b. p. 116-131.

MORENO, María Cristobalina. The address system in Spanish of the Golden Age. Journal of Pragmatics, v. 34, p. 15-47, 2002.

NOLL, Volker. O português brasileiro. São Paulo: Globo, 2008.

OLIVEIRA, Sandi Michele de. Negotiating identity, conflict, and cooperation within a strategic model of address. In: DENIS, Ann Denis; Kalekin-Fishman, Devorah (eds.), Contemporary Sociology. Conflict, competition, cooperation, Los Angeles, etc.: Sage, 2009. p. 416-432.

PACHECO, Miguel Ángel Quesada. Formas de tratamiento en Costa Rica y su evolución (1561-2000). In: HUMMEL, Martin; KLUGE, Bettina; LASLOP, María Eugenia Vázquez (eds.). Formas y fórmulas de tratamiento en el mundo hispánico, México (D.F.): El Colegio de México / Karl-Franzens-Universität Graz, 2010. p. 649-669.

RECUERO, Silvia Iglesias. Aportaciones al origen de '(la) vuestra merced' como forma de tratamiento. In: COMPANY, Concepción Company; ALBA, José G. Moreno de. (eds.), Actas del VII Congreso Internacional de Historia de la Lengua Española, vol. 2. Madrid: Arco Libros, 2008.

RIVERA, Daniel M. Sáez. 'Vuestra merced > usted': nuevos datos y perspectivas. In: TOVAR, José Jesús de Bustos; ALCONCHEL, José Luis Girón (eds.). Actas del VI 
Congreso Internacional de Historia de la Lengua Española. v. 3. Madrid: Arco / Libros, 2006. p. 2899-2911.

RUMEU, Márcia Cristina de Brito. Língua e sociedade: a história do pronome você no português brasileiro. Rio de Janeiro: Ítaca, 2013.

RUMEU, Márcia Cristina de Brito (in print). Variation in the paradigms of 'tu' and 'você': subject and complements in letters from Minas Gerais, Brazil, 1860-1989. In: HUMMEL, Martin; LOPES, Célia Regina dos Santos (eds.) (in print). Address in Portuguese and Spanish. Studies in diachrony and diachronic reconstruction. Series Topics in Address Research (TAR). Amsterdam / Philadelphia (John Benjamins).

SCHMÖLZER, Magdalena. El voseo en Cartago, Costa Rica. Master thesis, University of Graz, 2018.

SILVA, Vera Lúcia Paredes. Notícias recentes da presença do pronome 'tu' no quadro de pronomes do português falado no Rio de Janeiro. In: COUTO, Leticia Rebollo; LOPES, Santos (eds.). As formas de tratamento em português e em espanhol variação, mudança e funções conversacionais. Rio de Janeiro: Editora da Universidade Federal Fluminense, 2011.p. 213-242. p. 245-262.

SKÁRMETA, Antonio. El cartero de Neruda (Ardiente paciencia). Buenos Aires: Editorial Sudamericana, 1999 [1985].

SOSA, Enrique Obediente. Formas de tratamiento en Mérida (Venezuela) durante el siglo XVIII. Boletín de Lingüística, v. 21, n. 31, p. 86-107, 2009.

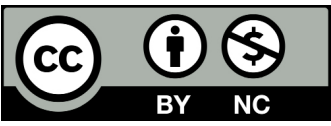

Data de submissão: 26/02/2019

Data de aceite: $18 / 11 / 2019$ 